高分子文集 (Kobunshi Ronbunshu), Vol. 44, No. 4, pp. 305-315 (Apr., 1987)

\title{
ジフェニル化合物のて解重合による薄膜生成及び生成膜の電気化学的举功
}

\author{
大坂 武男*1 ・吉村 文宏*1 - 大贯由紀夫*1 - 荻野 好美*2 ・ 中村 節子*2 - 小山 昇*1
}

(受付 1986 年 11 月 1 日・蓄查終了 1987 年 2 月 5 日)

\begin{abstract}
要 旨 アニリン及びフェノールが互いにそれぞれ4位に結合したジフェニル化合物（p-フェノキ シフニリン(PA), $p-フ_{x}$ ノキシフェノール(PP), 4丁ミノジフェニルフミン (ADA) 及び 4七ドロ キシジフェニルナミン (HDA)) の解酸化反応を程々の電解条件下で行い, 䑏生成の有無及び生成

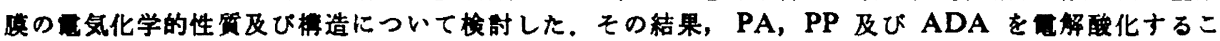

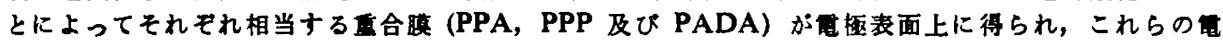

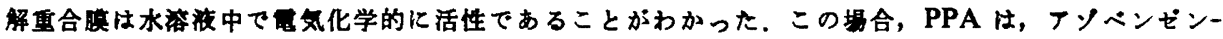

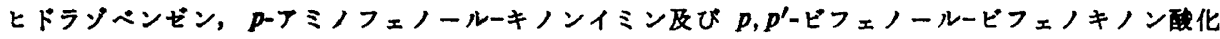

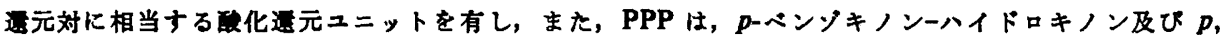
$\boldsymbol{p}^{\prime}$-ピフェノールーピフェノキノン酸化通元対に相当する酸化尰元ニニットを有することが明らかにな

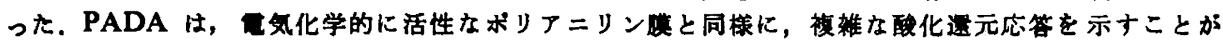

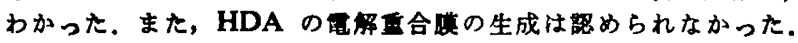

\section{1 櫣}

これまで，我々は，フミノ基あるいはヒドロキシル基 を有する考香族化合物（フニリンファノール及びこれ らの誘導体)を電解重合した場合，(i) 膜生成の有無， (ii) 重合膜の䨀造及び物性, そして (iii) 重合膜及び膜

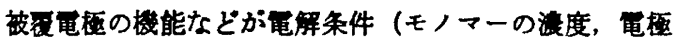
材料, 支持奄解貿, 溶媒, 液の $\mathrm{pH}$, 電流密度, 温度, 艃解モードなど）に強く依存することを明らかにしてき

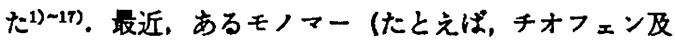
び 3-メチルチオフェン) を電解重合して作製した膜と そのモノマーのオリゴマー（たとえば，ターチオフェ ソ, 3,3'-ジメチル-2, 2'-ジチオフェン及び 3, 3',3'-トリ メチル-2, 2'，2"'-ターチオフェン) を龟解重合して作繁し た候とでは，膜の物性やモルホロジーなどが異なるこ とが報告されている(18) 20). そこで，本研究では，アニ リン及びフェノールが互いにそれぞれの4位に結合し

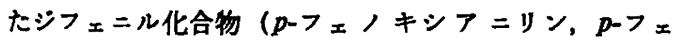
ノキシフェノール, 4ヒドロキシジフェニルアミン,及 び 4フミノシフェニルフミン (Fig. 1)) の電解酸化重 合反応を種々の電解条件下で行い, 䀧生成の有無, 及び 生成膜の奄気化学的性嘪及び構造などを調べ，更に得ら れた結果をアニリン,フェノールあるいはこれらの誘導

*1 東京蕽工大学工学部（184 小金井市中町 2-24 16)

*2 日本女子大学 (-112 東京都文京区目白台 2-8-1)
体の電解重合のそれと比較検討した。

\section{2 实検}

\section{1 試沗}

$p-フ ェ / キ シ フ ニ リ ン$ (Aldrich 社製，以下 PA と略 記する) 及び p-フェノキシフェノール (PP, Kodak 社 製) は，水から 2 回再結晶精製し，減压下で十分飞競燥 後使用した. 4-フミノジフェニルアミン (ADA, 两東 化学社製) は，水一エタノール混合溶媒から2 回再結晶 精製し使用した. 4とドロキシジフェニルフミン (HDA，東京化成(株) 制)はそのまま使用した。 pH 3.0,

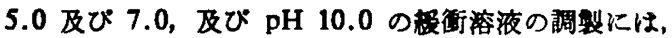
それぞれ，クエン酸ークエン酸ナトリウム、リン酸二水 索ナトリウムーリン䁃水菜二ナトリウム，及びホウ酸-水 酸化ナトリウム(いずれる和光純萝(株)製特級)を用い た.

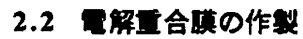

奄解重合は通常の三電極セルを用いて行った. 作用電 極として, basal-plane pyrolytic graphite (Union Carbide 社慗, 以下 BPG と略記する) を用い, 対極に は白金巻線電極, そして参照電極には飽和塩化ナトリウ ムカロメル電極（以下 SSCE と略記する）を用いた. 作用電極の面秒は，とくにことわらないかぎり，0.20 $\mathrm{cm}^{2}$ である.

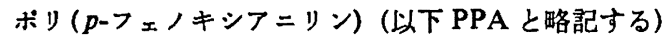
膜被覆軍極は, (i) $10 \mathrm{mM}\left(1 \mathrm{M}=1 \mathrm{~mol} \cdot \mathrm{dm}^{-3}\right) \mathrm{PA}$ 及 


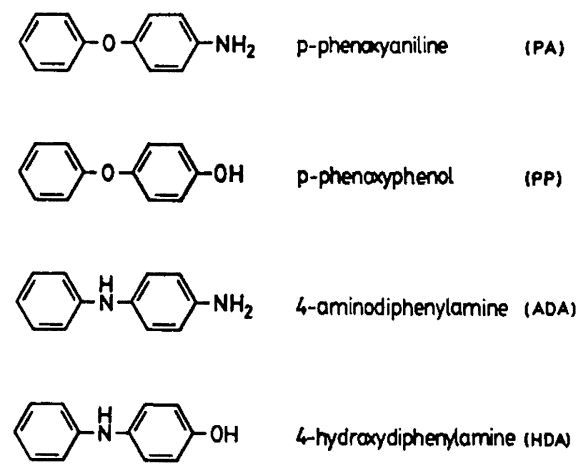

Fig. 1. Structures of the diphenyl compounds used.

び $0.2 \mathrm{M}$ 過塩菜酸ナトリウムを含む酸性水溶液 $(\mathrm{pH}$ 1.0) 中で $0.8 \mathrm{~V}$ (あるいは $1.2 \mathrm{~V}$ ) vs. SSCE での定䉓 位䉓解法, (ii) $0.1 \mathrm{M}$ PA 及び $0.2 \mathrm{M}$ 過塩秦酸ナトリ ウムを含むアセトニトリル溶液中で $1.6 \mathrm{~V}$ vs. SSCE で の定電位電解法, (iii) $2 \mathrm{mM}$ PA 及び $0.5 \mathrm{M}$ 硫酸ナト リウムを含む酸性水溶液 (pH 1.0) 中での䉓位拥引電解 法, 及び (iv) $7 \mathrm{mM}$ PA 及び $1 \mathrm{M}$ 硫酸を含む水一メ夕 ノール（体積比：70 対 30）混合溶液中での電位掃引電 解法によって作製した.

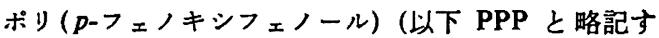
る)膜被鿉電極は, (i) $0.5 \mathrm{mM}$ PP 及び $0.5 \mathrm{M}$ 硫酸ナ トリウムを含む酸性水溶液 $(\mathrm{pH} 1.0)$ 中で $0.9 \mathrm{~V}$ (ある いは1.1 V) vs. SSCE での定電位奄解法，及び (ii) $0.1 \mathrm{M}$ (あるいは $10 \mathrm{mM}$ ) PP 及び $0.2 \mathrm{M}$ 過塩素酸ナ トリウムを含むてセトニトリル溶液中で $2.0 \mathrm{~V}$ vs. SSCE での定電位電解法により作製した.

ポリ (4フミノシフェニルアミン) (以下 PADA と略 記する) 膜被夏電極は, $10 \mathrm{mM}$ ADA 及び $0.2 \mathrm{M}$ 過塩 素酸ナトリウムを含む酸性水溶渡 $(\mathrm{pH} 1.0)$ 中で -0.6 $\sim 1.0 \mathrm{~V}$ vs. SSCE の奄位領娍での 電位捅引奄解法 (䉓 位纬引速度: $50 \mathrm{mV} \mathrm{s}^{-1}$ ) Кより作製した.

HDA の電解酸化反底を, (i) $10 \mathrm{mM}$ HDA 及び 0.2 $\mathrm{M}$ 過塩素酸ナトリウムを含む酸性水溶液 (pH 1.0)， (ii) $10 \mathrm{mM} \mathrm{HDA}, 30 \mathrm{mM}$ 水酸ナトリウム及び $0.2 \mathrm{M}$ 過塩素酸ナトリウムを含むメタノール溶液, 及び (iii) $10 \mathrm{mM}$ HDA 及び $0.2 \mathrm{M}$ 過坆粠酸ナトリウムを含む アセトニトリル溶液中で行ったが重合膜の生成はみられ なかった.

\section{3 測定洼是及ひ操作手順}

すへての電気化学測定は三電極式によって行った，作 用電極としては上述の奄解重合膜被覆 BPG あるいは未 被覆 BPG 電極，対極としては白金電極そして参照電極 としては SSCE を用いた. サイクリックボルタモグラ ムの測定には，当研究室で作製したボルタンメトリー装
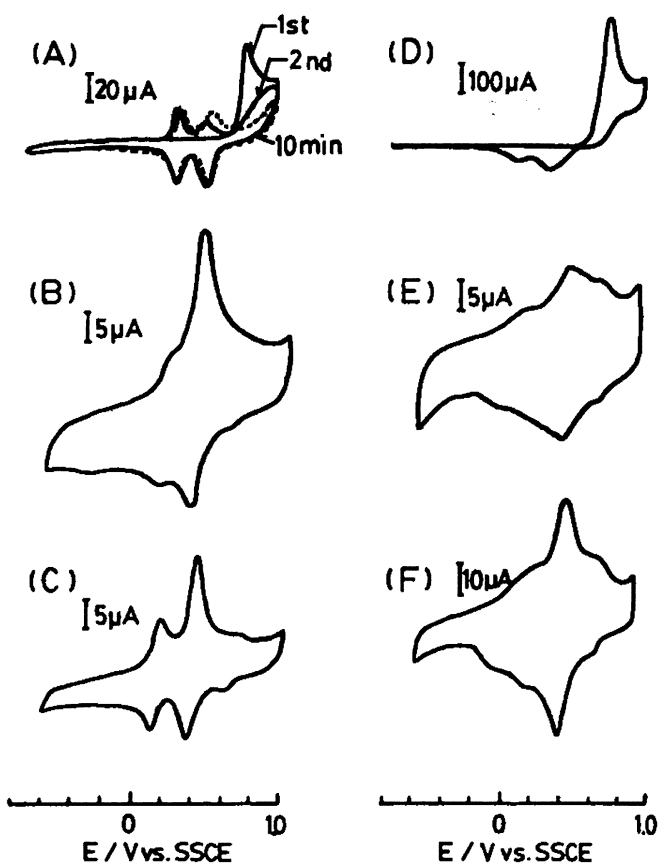

Fig. 2. (A): Cyclic voltammograms recorded during the electrochemical oxidation of PA at a BPG electrode in a PA (2 mM)- $\mathrm{Na}_{2} \mathrm{SO}_{1}(0.5 \mathrm{M})$ $\mathrm{H}_{2} \mathrm{SO}_{4}$ aqueous solution (pH 1.0). (B, C): Electrochemical responses of the PPA films prepared from the electrolytic solution used in $A$ in a $0.2 \mathrm{M} \mathrm{NaClO}$, solution (pH 1.0). (D): Cyclic voltammograms recorded during the electrochemical oxidation of PA at a BPG electrode in a PA $(10 \mathrm{mM})-\mathrm{NaClO},(0.1 \mathrm{M})$ acetonitrile solution. (E, F): Electrochemical responses of the PPA films prepared from the electrolytic solution used in $\mathrm{D}$ in a $0.2 \mathrm{M} \mathrm{NaClO}$, solution ( $\mathrm{pH} 1.0$ ). The films were prepared by a constant-potential electrolysis at (B) 1.0, (C) 0.8 , (E) 0.9 and (F) $1.1 \mathrm{~V}$ vs. SSCE. The charges passed to prepare the films were (B) 8.0, (C) 6.7 and $(E, F) 100 \mathrm{mC}$ $\mathrm{cm}^{-2}$. Scan rate: (A, D) 50; (B, C, B, F) 200 $\mathrm{mV} \mathrm{s}^{-1}$.

圈及び X-Y レコーダー (ダラフテック社製 WX 4400) を用いた．試料溶液の $\mathrm{pH}$ 測定には，ディジタル pH ๙ ーター(奄気化学計器 (株) 粒モデル HG-3) 及び pH ガラ ス電極（タイブ 6035）を用いた，電解重合の際作用 電極に流れた䉓気量は，東方技研(株) 紫のクーロメータ 一(3320)によって测定した，電解重合膜の膜原 $(\phi)$ 测定 は, 既報(5),10) 之同様に行った. 電解重合膜内の電気化学 的活性サイトの表面洤度 $(\Gamma)$ は， $0.2 \mathrm{M}$ 過塩素酸ナト リウム水溶液 $(\mathrm{pH} \mathrm{1.0)}$ 中で遈い西位掃引速度 $(2 \mathrm{mV}$ 


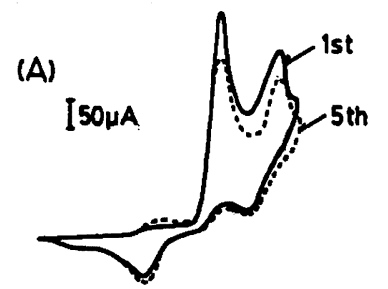

(D)

(B)
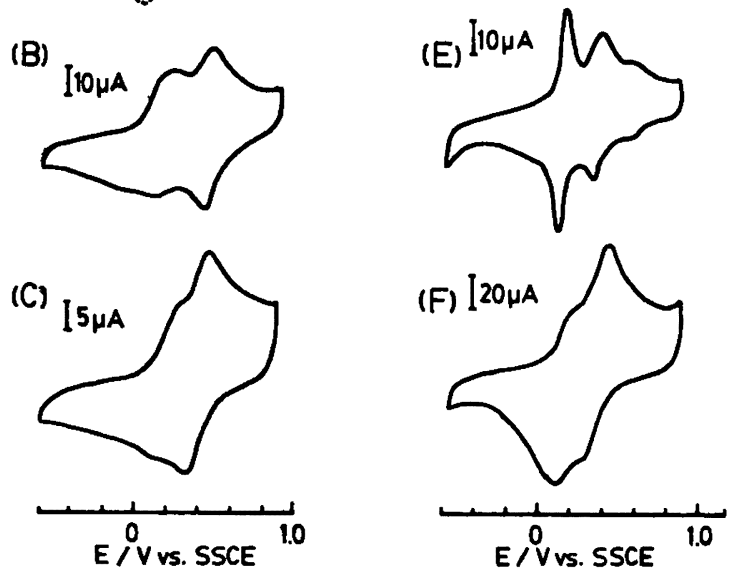

Fig. 3. (A): Cyclic vokammograms recorded during the electrochemical oxidation of $P A$ at a BPG electrode in a PA $(10 \mathrm{mM})-\mathrm{NaClO}_{4}(0.2 \mathrm{M})$ aqueous solution (pH 1.0). (B, C): Electrochemical responses of the PPA films prepared from the electrolytic solution used in $A$ in a $0.2 \mathrm{M} \mathrm{NaClO}$, solution (pH 1.0). (D): Cyclic voltammograms recorded during the elctrochemical oxidation of PA at a BPG electrode in a PA $(7 \mathrm{mM})-\mathrm{H}_{2} \mathrm{SO}_{1}(1.0 \mathrm{M}) \mathrm{CH}_{3} \mathrm{OH}(30 \%)-\mathrm{H}_{2} \mathrm{O}$ (70\%) solution. (E, F): Electrochemical responses of the PPA films prepared from the electrolytic solution used in $\mathrm{D}$ in a $0.2 \mathrm{M} \mathrm{NaClO}$, solution ( $\mathrm{pH}$ 1.0). The films were prepared by a constant-potential electrolysis at (B) $0.8,(C, F) 1.2$ and (E) $0.9 \mathrm{~V}$ vs. SSCE. Scan rate: (A, D) $50 \mathrm{mV} \mathrm{s}^{-1}$; (B, C, E, F) $200 \mathrm{mV} \mathrm{s}^{-1}$.

$\left.\mathrm{s}^{-1}\right)$ で得られたサイクリックボルタモクラムの四程分及 びクーロメトリーにより決定した，龟解重合膜の構造決 定のための赤外吸収スベクトル测定には，赤外吸収分光 計（JASCO A-302）を用いた，電気化学测定は，高純 度子ッ素ガスで試料溶液中の溶存酸索を除去した後，千 ッ菜ガス㞣囲気下で $25 \pm 1^{\circ} \mathrm{C}$ で行った。

\section{3 結果及び考寀}

\section{$3.1 p$-フェノキシアニリン (PA) の军解酸化反応及 び生成膜 (PPA) の空齐化学的举助}

Fig. 2 及び 3 は種々の奄解溶液中におけるPA の電 解酸化反応俍対するサイクリックボルタモグラムを示 す. いずれの場合にす，第一電位捧引において $0.6 \sim 1.0$ Vの奄位領城に一つあるいは二つの非可逆な酸化ビーク が覞察された．第一電位掃引の復路から約 0.2 及び 0.4 V vs. SSCE に新たな酸化䔔元ピークが䘽察された. フ セトニトリル溶液中での電解の場合を除いて，第二電位
掼引以後は, 非可逆な酸化波のピーク電流值が電位姗引 回数の增加とともに次第に減少した.これは，電極表面 が重合膜でおおわれ，その結果，PA の電極表面への拡 散が抑制されることによると考えられる。これに対し て，アセトニトリル溶液中での䉓解の䏆合には，PAの 膜内での拡散はより速いと考えられる。

定電位龟解法て作製した重合膜は，酸性水溶液（pH 1.0) 中で電気化学的に活性であり，0.2 0.6 V vs. SSCE の電位簀囲に 2 あるいは 3 組の酸化賟元反応に相 当する酸化僄元ビークが锶察された．この場合，定電位 電解時の奄解電位の違いによって, 瞙の酸化還元応答が 異なることがわかった．たとえば，硫酸水溶液中での䉓 解の場合 (Fig. 2B 及び C), 1.0 V vs. SSCE で定電位 奄解作製した膜では約 $0.4 \mathrm{~V} v$ v. SSCE に明確な酸化遙 元ピークか，そして 0.2 及び $0.6 \mathrm{~V}$ 付近に酸化遭元応答 が“ショルダー”として観察されたが， $0.8 \mathrm{~V}$ vs. SSCE で奄解作製した膜では， $0.2 \mathrm{~V}$ 及び $0.4 \mathrm{~V} v s$. SSCE 付 


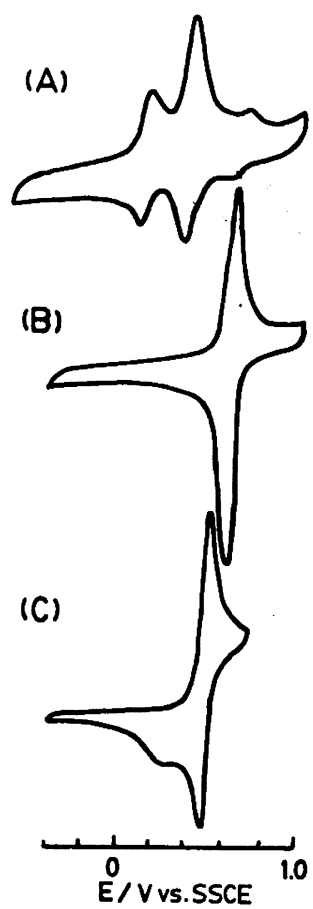

Fig. 4. Cyclic voltammograms of (A) a PPA film, (B) $p, p^{\prime}$-biphenol and (C) $p$-aminophenol at BPG electrodes in a $0.2 \mathrm{M} \mathrm{NaClO}$, solution ( $\mathrm{pH} 1.0$ ). Scan rate: $200 \mathrm{mV} \mathrm{s}^{-1}$. The PPA film was prepared by a constant-potential electrolysis at $0.8 \mathrm{~V}$ vs. SSCE in a PA (2 mM)- $\mathrm{Na}_{2} \mathrm{SO}_{4}(0.5 \mathrm{M})-\mathrm{H}_{2} \mathrm{SO}$, aqueous solution ( $\mathrm{pH} 1.0)$. The current scale is an arbitrary unit.

近に明確な二つの酸化還元ビークがみられ，そして 0.6 V 付近にわずかではあるが酸化寀元ピークがみられた。 龟解時の電解奄位の䢖いによる生成膜の酸化罢元応答の このような変化は，電解電位を変えることによって，生 成膜内の 3 種類のレド,クス対の相対的な数，すなわち 膜の組成か湾わることを示唆しているるのと思われる。

以上のことから，PA は蜩べた 4 稙類の電解溶液中で 军解酸化反応により面合膜を生成し，これらの膜は酸性 水溶液中で電気化学的に活性であることがわかった．次 K, PPA 膜といくつかのモデル化合物との酸化遚元応 答を比較することによって，これらの重合膜中に含まれ ている電気化学的に活性なサイトの棬造を検討した.

Fig. 4 は，酸性水溶液中に批引 PPA 膜， $p, p^{\prime}$ ービ フェノール及び p-フミノフェノールの酸化邆元反応に 対するサイクリックボルタモグムを表す。訹したよ 5飞, PPA 膜は約 $0.2,0.4$ 及び $0.6 \mathrm{~V}$ vs. SSCE K 酸化䏇元応答を示した。 $p$-フミノフェノール及び $p, p^{\prime}-$ ビフェノールの酸化遣元応答はそれぞれ 0.4 及び $0.6 \mathrm{~V}$

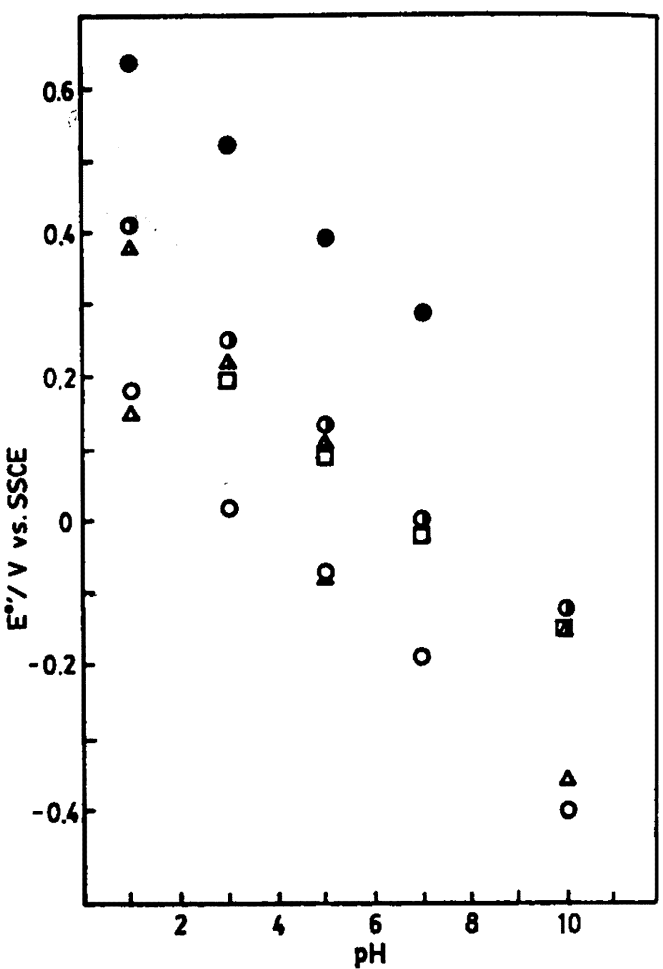

Fig. 5. pH dependences of the formal redox potentials $\left(E^{\circ}\right)$ for the oxidation-reduction reaction of the PPA films deposited on BPG electrodes in buffer solutions containing $0.2 \mathrm{M} \mathrm{NaClO}$, as a supporting electrolyte. The films were prepared from a PA (7 mM)- $\mathrm{H}_{2} \mathrm{SO}_{4}(1.0 \mathrm{M}) \mathrm{CH}_{8} \mathrm{OH}(30 \%)-$ $\mathrm{H}_{2} \mathrm{O}(70 \%)$ solution by a constant-potential electrolysis at $(O, O, \bullet) 0.9$ and $(\Delta, \Delta) 1.2 \mathrm{~V}$ vs. SSCE, and ( $\square$ ) from a PA (0.1 M)-NaClO، (0.2 M) acetonitrile solution by a constant-potential electrolysis at $1.6 \mathrm{~V} v s$. SSCE.

vs. SSCE 付近に钼察され，また，フソペンせンのそれ は約 $0.2 \mathrm{~V}$ と報告されている21)。こうして，PPA 䀧の $0.2,0.4$ 及び $0.6 \mathrm{~V}$ vs. SSCE の酸化遗元応答は，そ れぞれアソペンゼンーヒドラソベンゼン，p-フミノフェ

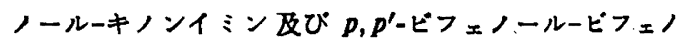
キノンの酸化通元対の酸化遮元応答と一致し，PPA 重 合膜はこれらの酸化還元対に対応する構造を有する酸化 趂元ニニットを含んでいると考えられる.それぞれの酸 化通元ニニットの酸化遮元反度恃以下のよらに表され

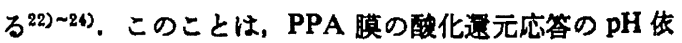
存性からる支持される。

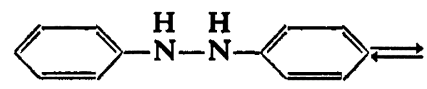

高分子垥文集，Vol. 44，No. 4 (1987) 


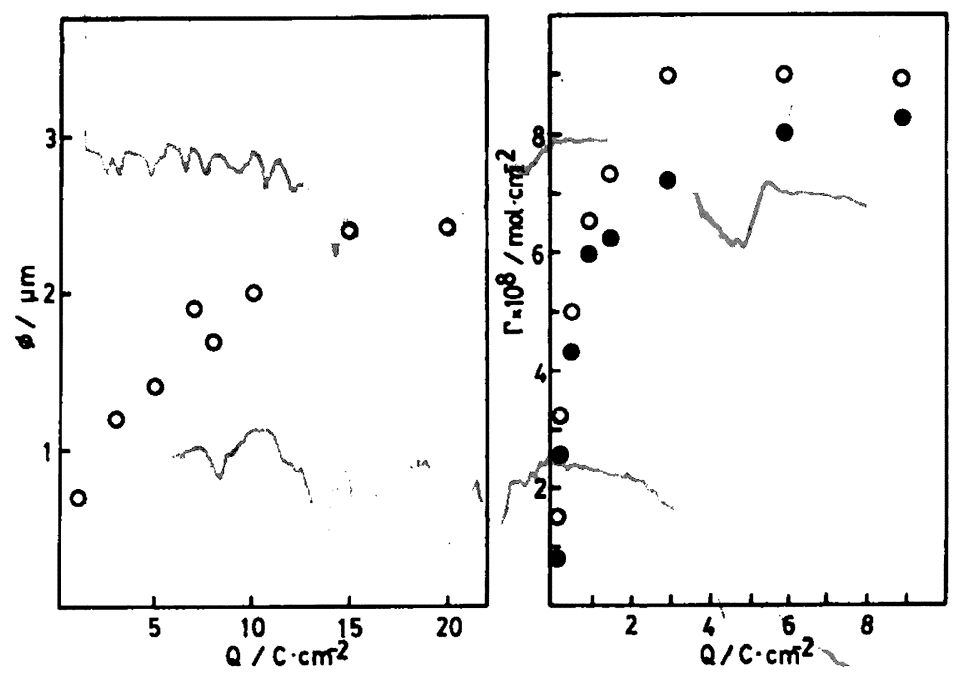

Fig. 6. Plots of the film thickness $(\phi)$ and surface concentration of electroactive sites $(\Gamma)$ vs. the charge $(\mathrm{Q})$ passed to prepare PPA films. The films were prepared from a PA $(0.1 \mathrm{M})$ NaClO, $(0.2 \mathrm{M})$ acetonitrile solution by a constant-potential electrolysis at $1.6 \mathrm{~V}$ vs. SSCE. $(O)$ : Estimated from the oxidation reaction; $(0)$ : Estimated from the reduction reaction.

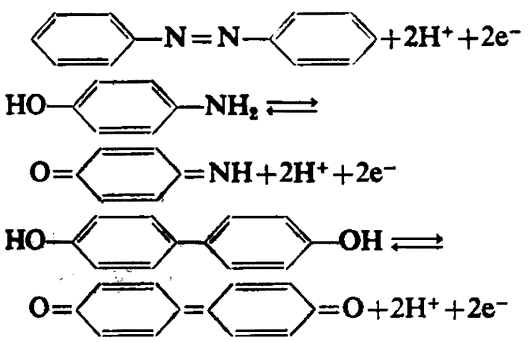

すなわち，PPA 瞙の酸化逷元対の酸化遙元反応に相当

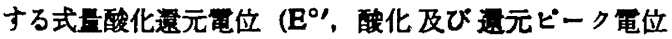
の平均値として評洒される) の $\mathrm{pH}$ 依存性を調べた結果 (Fig. 5), E⿰冫 vs. pH のプロ,トの勾医はいずれの㘯合 にも約 $-60 \mathrm{mV} / \mathrm{pH}$ でっった.このことは, これら3 組の奄極反応にブロトンと電子が 1 奶 1 で网与すること を示唆し，また，式 (1)〜(3) で表される反応村して 期待されるすのである.

PA は、アニリンとフェノールとの別程のモノマーか ら成る二量体の粠造を有するが，電解酸化によって酸化 される官能基はフミノ基であるために䉓解直合反応によ

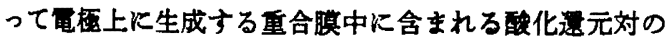
權造は，ヒドロキシル基の電気化学的酸化により生成す る中間体のカップリンク反応化よる酸化退元対よりはむ しろ, アミノ基の酸化により生しる中間体のカッブリン ク反応に上って生成すると期等される酸化违元対の粠造 に対応している. フンリンの奄解酸化の場合には，電解 酸化によって生成する中间体の頭一頭, 頭一尾及び尾一
尾結合によって，それぞれヒドラソベンぜン，4ーアミ，

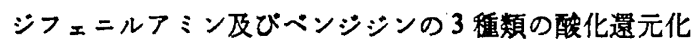
学種が生成し ${ }^{25), 28)}$, 更に, 4フミノジフェニルフミンは 加水分解して 4アミノフェノールになり23), これらに対 応する酸化逥元ニニットがポリアニリン膜中に含まれて いると考えられている38,25),27),28)。同棣に, PA の重合 膜中にも，PA の電解酸化反応で生成する中間体が頭一 頭, 頭一尾, 及び尾一尾結合によって生成するフソペン ゼンーヒドラソペンゼン, アミノフェノールーキノンイミ ン及びピフェノールービフェノキノンの酸化還元対に対 応する酸化選元ニニットが含まれていると推定できる. この均合、アミノ基に対してр位がフィキシ基でプロ ックされているので，頭一尾及び尾一尾結合の尾はフ / 基に対する。位に相当する.ここで，尾一尾結合によ って生しる酸化遙元対はベンジジンタイブの構造をして いるが、これは加水分解によりビフェノールービフェ キノンタイプのそれになると考えられる.

Fig. 6 は, PPA 膜生成に怙ける通電電気量 $(Q)$ と 膜厚 $(\phi)$ 及び膜内での電気化学的に活性なレドックスサ イトの表面港度 $(\Gamma)$ との関係を表す. $\phi$ は $Q$ が約 15

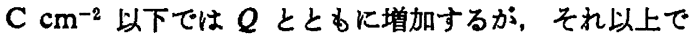
は， $\phi$ は汪とんど增加しない，同粎に，Q<約 $2 \mathrm{C} \mathrm{cm}^{-2}$ では， $\Gamma$ は $Q$ に注比例して增加するが， $Q>2 \mathrm{C} \mathrm{cm}^{-2}$ では，Q が增加しても $\Gamma$ は汪とんど增加しないことが わかる.このことは，膜内のレットッゥクス活性サイトの 体程灌度 $(C=\Gamma / l)$ は $\phi$ ととすに変わることを意味し 


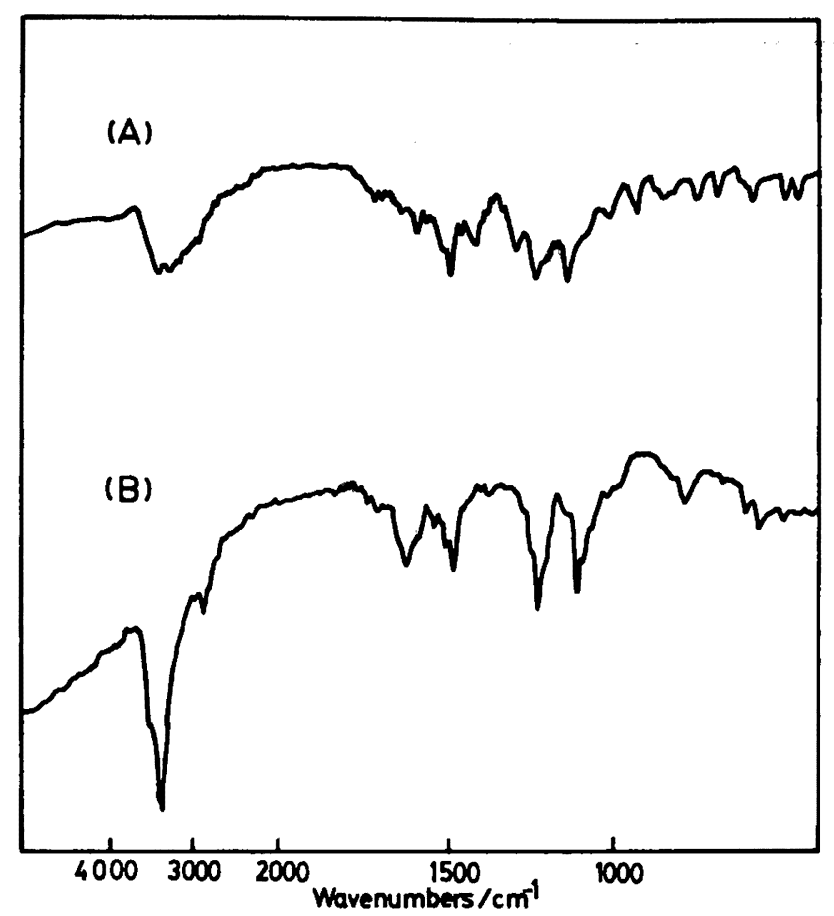

Fig. 7. IR absorption spectra of the PPA films. The PPA films were prepared on BPG electrodes from (A) a PA (7 mM)- $\mathrm{H}_{2} \mathrm{SO}_{4}(1.0 \mathrm{M}) \mathrm{CH}_{8} \mathrm{OH}(30 \%)-\mathrm{H}_{2} \mathrm{O}(70 \%)$ solution at $0.9 \mathrm{~V}$ vs. SSCE and (B) a PA (7 mM)-NaClO, (0.2 M) solution ( $\mathrm{pH} \mathrm{1.0)}$ at $0.6 \mathrm{~V}$ vs. SSCE.

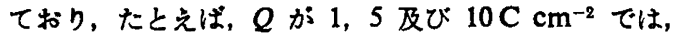
$C$ はそれぞれ $8.9 \times 10^{-4}, 5.9 \times 10^{-4}$ 及び $4.3 \times 10^{-4} \mathrm{~mol}$ $\mathrm{cm}^{-8}$ であった.このことは，申が大きくなると，本来 は龟気化学的に活性であるか，たとえば微視的にみて十 分に膨澊していないよらな高分子ドメインに存在してい るサイトは恰出されないことによると考えられる。な お，乾嬠状寍での PPA 膜の電学度 $(\sigma)$ は，用いた電解 溶液の種類及び膜厚 $(0.03 \sim 0.2 \mu \mathrm{m})$ によらず約 $5 \times$ $10^{-0} \mathrm{~S} \mathrm{~cm}^{-1}$ てあった.

Fig. 7 は, PPA 膜の赤外吸収スペクトルを表す. $3400 \sim 3450 \mathrm{~cm}^{-1} \mathrm{kN}-\mathrm{H}$ 伸縮振轩, $1620 \sim 1640 \mathrm{~cm}^{-1}$ $k \mathrm{C}=\mathrm{N}$ 伸縮振動， $1500 \mathrm{~cm}^{-1} k \mathrm{C}=\mathrm{C}$ 面内伸縮振動, $1220 \sim 1260 \mathrm{~cm}^{-1}$ Kエーテル結合の $\mathrm{C}$ - $\mathrm{O}$ 伸縮振動, $1120 \sim 1140 \mathrm{~cm}^{-1}$ 及び $800 \mathrm{~cm}^{-1}$ に 1,2,4ペンゼン三置 換体あるいはペンゼン一睓换体の C-H 面外変角振動に 相当する吸収がみられた ${ }^{28)}$.ここで, $1120 \sim 1140 \mathrm{~cm}^{-1}$ の吸収スベクトルには，エーテル結合の CDO 対称伸 樎振動も含まれていると考えられる29). エーテル結合に 㷌属される吸収が観察されたことより，上で述べたよう に, 重合に関与するのはアミ/基であると推定される. また，PPA 膜は電解酸化する䉓位によって重合膜の 3 組の酸化僄元対に相当する電流応答の大きさが巽なる。
これは， $\mathbf{N}-\mathbf{N}$ 結合 (頭一頭結合)， $\mathbf{C}-\mathbf{N}$ 結合（ア シ /基に対してォルト位での頭一尾結合) 及び C-C 結 合 (フミノ基に対してオルト位での尾一尾結合) の形成 割合が電位によって異なるためであると推定される。

\section{2 p-フェノキシフェノール (PP) の解儤化反芯}

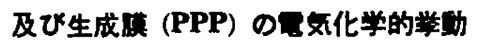

Fig. 8 は，PP の酸性水溶液及びアセトニトリル溶葆 中での電解酸化反应及び生成膜の酸性水溶液中での酰化 摙元反応に対するサイクリックボルタモクラムを表す。 酸性水溶液中での龟解の場合, 二つの非可逆な酸化ピクが 0.7 及び $1.1 \mathrm{~V}$ vs. SSCE 付近に钼察された(掊 引速度：50 $\mathrm{mV} \mathrm{s}^{-1}$, Fig. 8A). 第一龟位掊引の復路加 50.4 及び $0.6 \mathrm{~V} v s$. SSCE 付近に新しい可逆な酸化 運元応答が現れた。これは，第一龟位披引中K PP か酸 化されて電梗表面に生成した奄解重合膜 (PPP) 自身に よる酸化僄元応答である. 電位擩引回数の增加ととすに 非可逆な酸化ピーク電位はしたいに減少した (Fig. 8A). これは，電極表面が重合膜でおおわれ，その結果， PP の䉓極表面への拡散が㧕制されることによると考兄

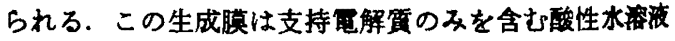
中で，約 0.4 及び $0.6 \mathrm{~V}$ vs. SSCE に酸化遥元応答を

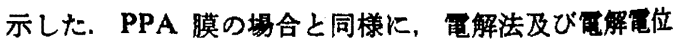



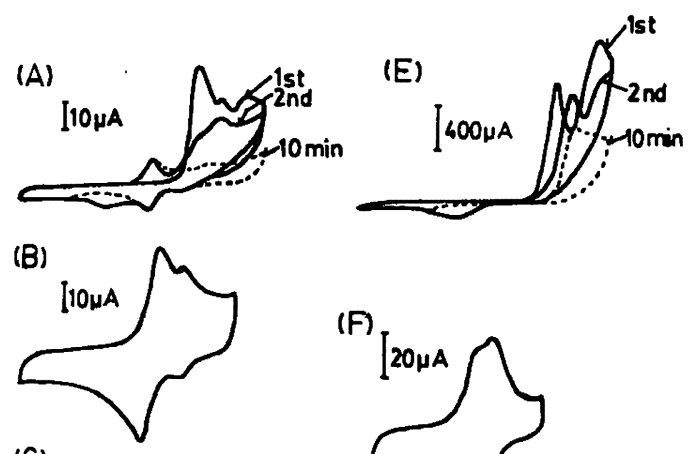

(C)
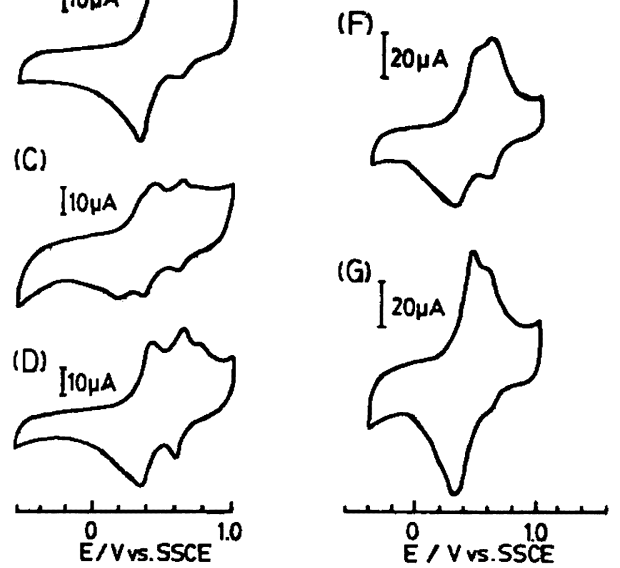

Fig. 8. (A): Cyclic voltammograms recorded during the electrochemical oxidation of PP at a BPG electrode in a PP $(0.5 \mathrm{mM})-\mathrm{Na}_{2} \mathrm{SO},(0.5 \mathrm{M})-$ $\mathrm{H}_{2} \mathrm{SO}$, solution (pH 1.0). (B, C, D): Electrochemical responses of PPP films prepared from the electrolytic solution used in $A$ in a $0.2 \mathrm{M}$ $\mathrm{NaClO}_{4}$ solution ( $\mathrm{pH}$ 1.0). (E): Cyclic voltammograms recorded during the electrochemical oxidation of PP at a BPG electrode in a PP (10 mM)$\mathrm{NaClO}_{4}(0.2 \mathrm{M})$ acetonitrile solution. $(\mathrm{F}, \mathrm{G})$ : Electrochemical responses of PPP films prepared from the electrolytic solution used in $E$ in a $0.2 \mathrm{M} \mathrm{NaClO}$, solution ( $\mathrm{pH} 1.0$ ). The films were prepared by (B) cycling the potential sweep between -0.6 and $1.2 \mathrm{~V}$ vs. SSCE at $50 \mathrm{mV} \mathrm{s}^{-1}$, and by a constant-potential electrolysis at (C, F) 1.2 , (D) 0.9 and (G) $1.5 \mathrm{~V}$ vs. SSCE. Scan rates: (A, E) $50 \mathrm{mV} \mathrm{s}^{-1}$; (B, C, D, F, G) $200 \mathrm{mV} \mathrm{s}^{-1}$. The charges passed to prepare the films were (C) 10 , (D) 6.0 and $(F, G) 150 \mathrm{mC} \mathrm{cm}^{-2}$.

によって PPP 膜の酸化遭元応答が異なることがかかる (Fig. 8B, C 及び D).

次に, アセトニトリル溶液からの PP の薢酸化反応 の场合について考える. 電解酸化反応のサイクリックポ ルタモグラム (Fig. 8E) から明らかなように，第一電 位揭引において 1.1 及び $1.4 \mathrm{~V}$ vs. SSCE 付近に非可 逆な二つの酸化ピークが锶察された. これらは，PP ノマーのカチオンラジカルヘの酸化及びカチオンラジカ
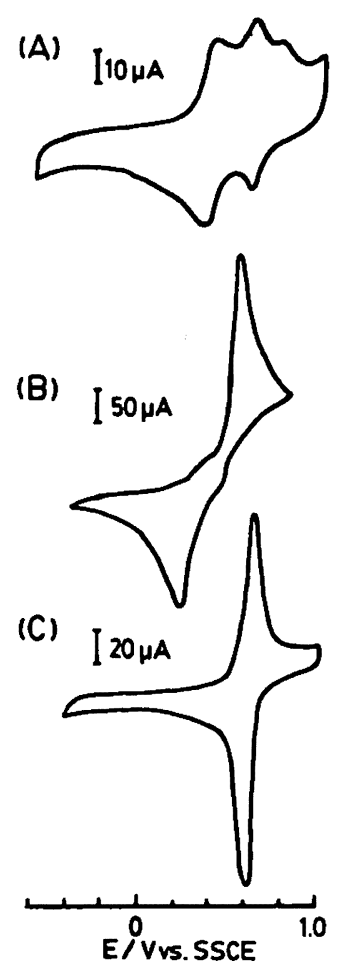

Fig. 9. Cyclic voltammograms of (A) PPP film, (B) $p$-benzoquinone and (C) $p, p^{\prime}$-biphenol at BPG electrodes in a $0.2 \mathrm{M} \mathrm{NaClO}$, solution $(\mathrm{pH}$ 1.0). Scan rate: $200 \mathrm{mV} \mathrm{s}^{-1}$. The PPP film was prepared by a constant-potential electrolysis at $0.9 \mathrm{~V}$ vs. SSCE in a PP (0.5 mM)- $\mathrm{Na}_{2} \mathrm{SO}_{4}(0.5 \mathrm{M})$ $\mathrm{H}_{2} \mathrm{SO}_{4}$ solution (pH 1.0).

ルのジカチオンへの酸化に相当していると考えられる. 生成した膜被要電極をアセトニトリルで洗浄後，支持䉓 解资のみを含む酸性水溶液中に移してその酸化僄元応答 を調へた結果，0.4 及び $0.6 \mathrm{~V}$ vs. SSCE 付近に可逆な 酸化壝元応答かみられ，これは酸性水溶液中から BPG 電極上に生成した骐のそれと同じ龟位であった. このこ とは，酸性水溶液及びアセトニトリル溶液から作製した PPP 膜は同じレドックス対を有することを示唆してい る.

Fig. 9A に PPP 䀧の酸性水溶液 (pH 1.0) 中におけ る酸化還元応答を示すサイクリックボルタモグラムを示 した. 此較のために, 同じ酸性水溶液に p-ベンソキ, ン及び $p, p^{\prime}$-ピフェノールを溶存化学種として溶解し, 祝の BPG 電極によってその酸化邆元反応を調べた結果 を Fig. 9B 及びCに示した. PPP 膜は， 0.4 及び 0.6 V vs. SSCE 付近に可逆な酸化買元応答を示し，また，

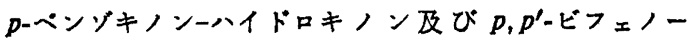




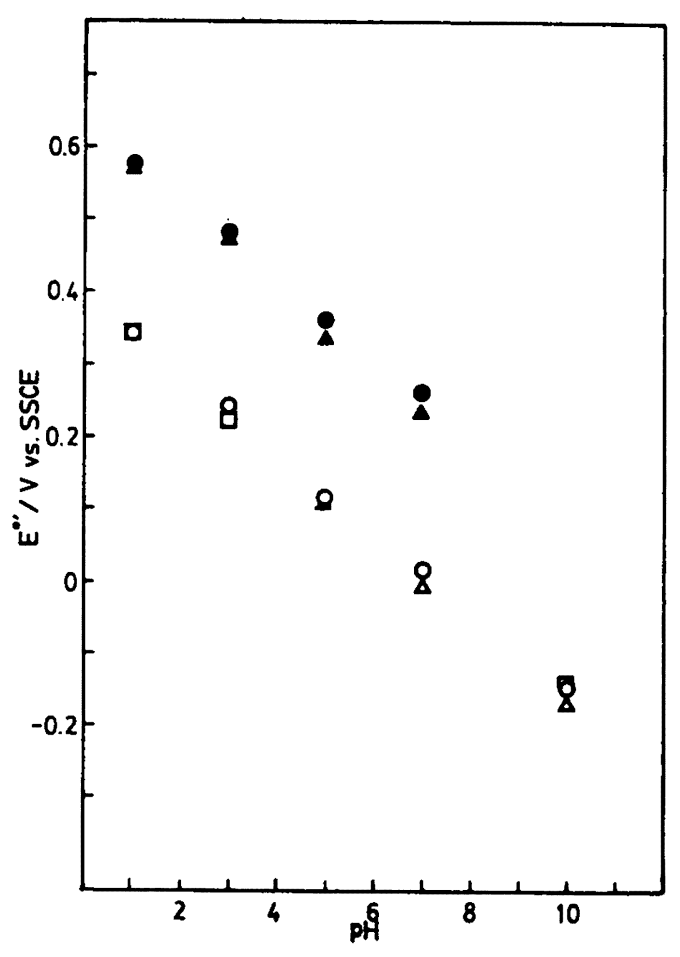

Fig. 10. pH dependences of the formal redox potentials $\left(E^{\prime \prime}\right)$ for the oxidation-reduction reaction of the PPP films deposited on BPG electrodes in the same solutions as used in Fig. 5. The films were prepared from a PP $(0.5 \mathrm{mM})$ $\mathrm{Na}_{2} \mathrm{SO}_{4}(0.5 \mathrm{M})$ aqueous solution ( $\left.\mathrm{pH} 1.0\right)$ by a constant-potential electolysis at $(O, 0) 0.8$ and $(\triangle, \triangle) 1.1 \mathrm{~V} v s$. SSCE and ( $\square$ ) from a PP (0.1 M)$\mathrm{NaClO}_{4}(0.2 \mathrm{M})$ acetonitrile solution at $2.0 \mathrm{~V} v$ s. SSCE.

ルービフェノキノンの酸化通元対の酸化罣元電位はそれ ぞれ 0.4 及び $0.6 \mathrm{~V}$ vs. SSCE である.こらして, PPP 獏の 0.4 及び $0.6 \mathrm{~V}$ での酸化㯰元応答はそれぞれ p-ベ ンソキノンーハイドロキノン及び $p, p^{\prime}$ ビフェノールービ フェノキノン酸化寀元対の酸化遗元反応作相当すると考 えられる.したがって，PPP 膜はキノンーハイドロキノ ン対及びビフェノールービフェノキノン対の 2 鍾類の酸 化僈元対に対応する楼造を有する酸化嘾元ニニットを含 むと推定される.

Fig. 10 は，PPP 膜の 2 組の酸化這元対の酸化摆元応 答に相当する式量酸化迕元軍位 $\left(E^{\circ \prime}\right)$ の $\mathrm{pH}$ 依存性を 示す. どちらの㘯合む， $E^{\circ \prime}$ vs. $\mathrm{pH}$ のブロットの勾配 はほぼ $-60 \mathrm{mV} / \mathrm{pH}$ であり，これら両方の酸化罢元対 の奄極反応はプロトンと奄子が 1 対 1 で関与した反応で あることが確められた．この結果は，キノンーハイドロ
キノン酸化罢元対及びビフェノールービフェノキノン酸 化頲元対の酸化遭元反底に 対する $E^{\circ \prime} の \mathrm{pH}$ 依存性 と 一致する.

Fig. 11 は，PPP 膜生成時の通䉓䉓気量 $(Q)$ とその ときの膜原 $(\phi)$ 及び膜内での電気化学的活性サイトの表 面濃度 $(\Gamma)$ との成保を表す。 $Q$ か $11 \mathrm{C} \mathrm{cm}^{-2}$ 加 $70 \mathrm{C}$ $\mathrm{cm}^{-2}$ へ增加するにつれて $\phi$ は 0.5 か.5 $3.1 \mu \mathrm{m}$ へ增 加する. しかしながら， $Q$ か $70 \mathrm{C} \mathrm{cm}^{-2}$ 以上では $\phi$ は ほぼ一定となり，膜成長は事実上起こらないと考えられ る. 同様の傾向は $\Gamma$ についてもいえる.たたしこの 場合には, $Q$ が約 $3 \mathrm{C} \mathrm{cm}^{-2}$ 以上では $\Gamma$ の值はほぼー 定値を示した.これらの結果は，3.1のPPP 膜の场合 と同様に説明される.

\subsection{4-アミノジフェニルアミン (ADA) 及び 4-ヒト ロキシジフェニルアミン (HDA) の露解化反 㐫}

上述した PA 及び PP と異なり， ADA 及び HDA は酸性水溶液及びアセトニトリル溶液中で可逆な酸化退 元応答をした (Fig. 12). 酸性水溶液中でのこれらのシ $フ_{x}$ ニル化合物の可逆な酸化量元応答は約 $0.4 \mathrm{~V}$ vs. SSCE にあり，PA 及びPP の電解酸化反応の場合に みられるような非可逆な酸化ピークは $1.5 \mathrm{~V}$ vs. SSCE の電位範囲まて覩察されなかった，ADA 及びHDA と 類似の粠造を有する $p$-フェニレンジフミンや p-フミ， フェノールの醉化還元応答はすでに報告されている30). これらの化合物の酸性水溶液中 $(\mathrm{pH} \mathrm{1.0)}$ での酸化量元 奄位は約 $0.4 \mathrm{~V}$ vs. SSCE にあり (Fig. 12)，HDA 及 び ADA のそれと一致している.

酸性水溶液及びフセトニトリル溶液中で，-0.6 1.0 V vs. SSCE の電位範囲で電位䛺引を繰り返すことによ って，ADA の電解重合膜 (PADA) が得られた。 PADA 膜の酸性水溶液中での酸化摆元応答は，襀䧴で， 酸性水溶液中から電解重合したボリアニリンのそれと類 似していることがわかっだ(1),31),32)，PADA 膜の生成 は，佐々木らによっても報告されている33). PADA 膜 のIR スペクトルにおいて (Fig. 13)，1100 1120 $\mathrm{cm}^{-1}$ に 1,4ペンゼン二粗換体の $\mathbf{C}-\mathbf{H}$ 面外变角振動及び $880 \mathrm{~cm}^{-1}$ に $1,2,4$ ベンゼン三置換 体 の C-H 面外変 角振動に相当する吸収が観察された29)。このことより， PADA はアミ/基（あるいはイミ/基）に対してオル ト位やバラ位で結合した棬造になっていると推定され る.

これに対して，HDA の場合，用いた電解溶液中での 電解酸化反庍によって相当する重合膜の生成はみられな かった．HDAを含むアセトニトレル溶液中で， -0.6 $\sim 1.4 \mathrm{~V}$ vs. SSCE の電位籁囲で数十回電位措引(50 $\mathrm{mV} \mathrm{s}^{-1}$ で) した電極と，新たな奄極面を切り出した BPG 電極を HDA のアセトニトリル溶液中に浸せきし 

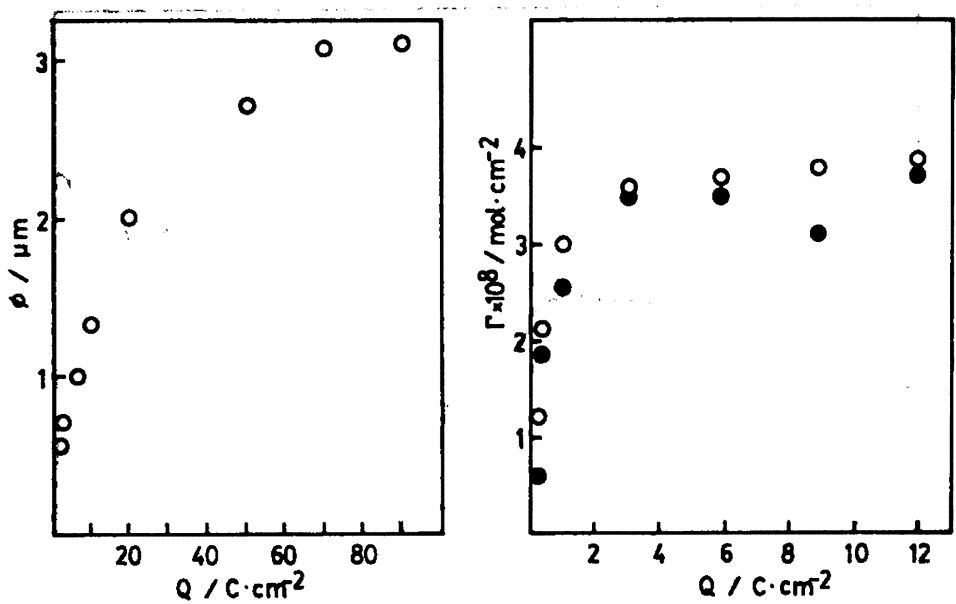

Fig. 11. Plots of the film thickness $(O)$ and the surface concentration of electroactive sites $(\Gamma)$ vs. the charge (Q) passed to prepare PPP films. The films were prepared from a PP $(0.1$ $\mathrm{M})-\mathrm{NaClO}_{4}(0.2 \mathrm{M})$ acetonitrile solution by a constant-potential electrolysis at $2.0 \mathrm{~V}$ vs. SSCE. $(0)$ : Estimated from the oxidation reaction; (O): Estimated from the reduction reaction.
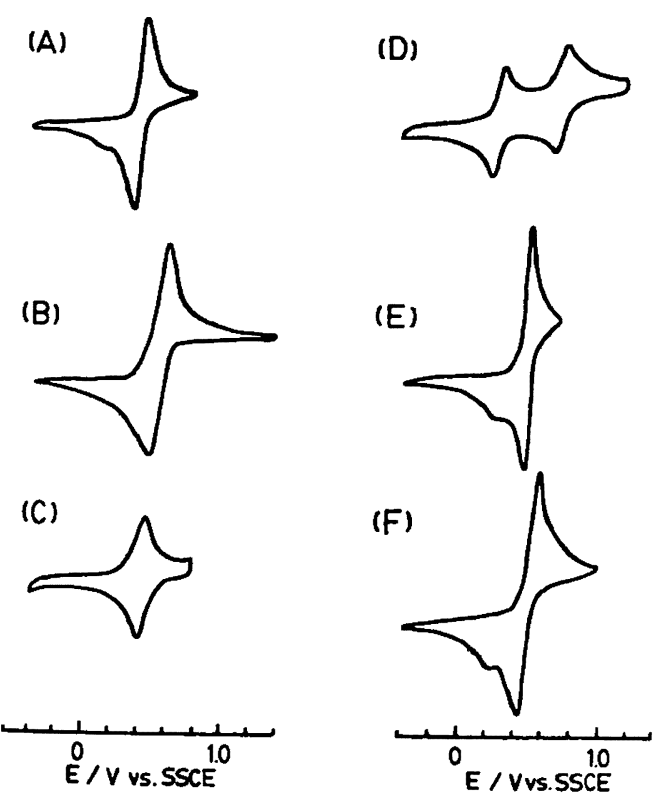

Fig. 12. Cyclic voltammograms of (A, B) HDA, (C, D) ADA, (E) $p$-aminophenol and (F) p-phenylenediamine. Supporting electrolytes: $(A, C$, E, F) $0.2 \mathrm{M} \mathrm{NaClO},-\mathrm{HClO}_{4} / \mathrm{H}_{2} \mathrm{O}$ (pH 1.0); (B, D) $0.2 \mathrm{M} \mathrm{NaClO}_{4} /$ acetonitrile. Scan rate: $200 \mathrm{mV}$ $\mathbf{s}^{-1}$. The current scale is an arbitrary unit.

溶媒を乾嬠させた電極とを，0.2 M 過塩菜酸ナトリウ 么水溶液 (pH 1.0) 飞移して酸化罢元応答を調べた結 果, どちらの奄極です約 $0.4 \mathrm{~V}$ vs. SSCE に可逆な酸化
速元応答がみられまた，ピーク電流値の大きさむほぽ 同じであったこのことより，アセトニトリル溶液中で 電解を行った電極を酸性水溶液に移した場合に得られる 酸化還元応答は，電解重合膜のそれによるものではな く、電極表面に強く吸着した HDA モノマーの酸化噌 元反応によることがかかった。

\section{4 結 篟}

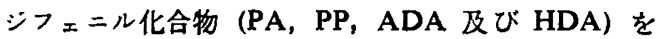
種々の電解条件下で電解酸化し，膜生成の有無及び生成 膜の電気化学的性質及び構造を調べることにより，以下 の知見が得られた。

1) PA，PP 及び ADA を電解酸化することによっ て，電極上にそれぞれ相当する重合膜（PPA，PPP 及 び PADA）が得られた。これらの重合膜は水溶液中で 酸化遙元応答を示した．また，この揚合の電極反応はブ ロトンと電子が 1 対 1 で関与している反応であることが 明らかにされた。

2) PPA はフソペンゼンーヒドラソベンゼン, p-דミ

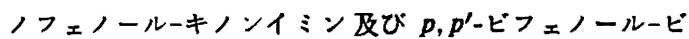

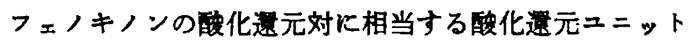
を有し，また，PPP は p-ペンソキノンッイドロキノン 及び $p, p^{\prime}$ ービフェノールービフェノキノンの酸化還元対 に相当する酸化䚈元ニニットを有することがわかった.

3）調へたた電解溶液及び電解条件下では，HDA の重 合膜の生成は認められなかった.

4）電解時の通電量を変えることによって，PPA 膜 の場合には約 0.7 から $2.5 \mu \mathrm{m}$, そして PPP 膜の場合 には約 0.5 から $3.2 \mu \mathrm{m}$ の重合膜が得られた. 


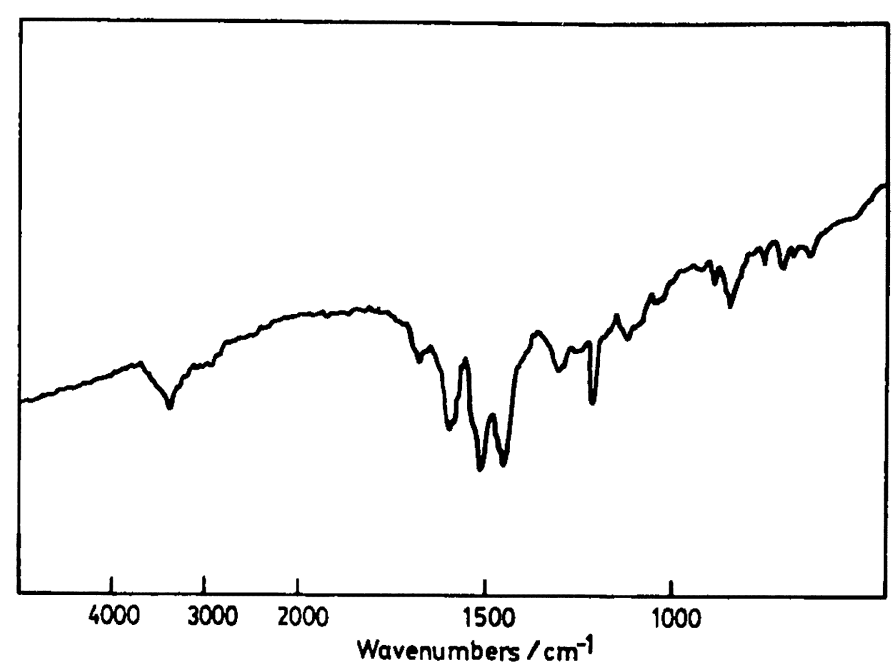

Fig. 13. IR absorption spectrum of the PADA film prepared by a constant-potential electrolysis at $0.7 \mathrm{~V}$ vs. SSCE in a ADA (10 mM)- $\mathrm{NaClO}_{4}(0.2 \mathrm{M})$ aqueous solution ( $\left.\mathrm{pH} 1.0\right)$.

期辞 本研究费の一部は, 文部省科学研究费補助金 (60211011) 及び昭和 60 年度日産学術研究助成金によ った。ここに記して感即します。

\section{文献}

1) N. Oyama, Y. Ohnuki, K. Chiba, and T. Ohsaka, Chem. Lett., 1759 (1983).

2) Y. Ohnuki, T. Ohsaka, H. Matsuda, and N. Oyama, J. Electroanal. Chem., 158, 55 (1983).

3) T. Ohsaka, Y. Ohnuki, N. Oyama, G. Katagiri, and K. Kamisako, J. Electroanal. Chem., 161, 399 (1984).

4) Y. Ohnuki, H. Matsuda, and N. Oyama, Nippon Kagaku Kaishi, 1801 (1984).

5) N. Oyama, K. Chiba, Y. Ohnuki, and T. Ohsaka, Nippon Kagaku Kaishi, 1172 (1985).

6) N. Oyama, T. Ohsaka, and T. Shimizu, Anal. Chem., 57, 1526 (1985).

7) T. Ohsaka, T. Okajima and N. Oyama, $J$. Electroanal. Chem., 200, 159 (1986).

8) T. Osaka, K. Chiba, and N. Oyama, Nippon Kagaku Kaishi, 457 (1986).

9) N. Oyama, T. Ohsaka, and M. Nakanishi, J. Macromol. Sci. Chem., A24, 375 (1987).

10) N. Oyama, K. Hirabayashi, and T. Ohsaka, Bull. Chem. Soc. Jpn., 59, 2071 (1986).

11) T. Ohsaka, K. Hirabayashi, and N. Oyama, Bull. Chem. Soc. Jpn., 59, 3423 (1986).

12) K. Chiba, T. Ohsaka, Y. Ohnuki, and N. Oyama, J. Electroanal. Chem., 217, 239 (1987).

13) K. Chiba, T. Ohsaka, and N. Oyama, $J$. Electroanal. Chem., in press.
14) T. Ohsaka, T. Okajima, and N. Oyama, $J$. Electroanal. Chem., 215, 191 (1986).

15) N. Oyama and T. Ohsaka, Synth. Metals. 18, 375 (1987).

16) N. Oyama, T. Ohsaka, Y. Ohnuki, and T. Suzuki, J. Electrochem. Soc., in press.

17) T. Ohsaka, T. Hirokawa, H. Miyamoto, and N. Oyama, Anal. Chem., in press.

18) Y. Yumoto and S. Yoshimura, Synth. Metals, 13, 185 (1986).

19) H. B. Mark, Jr. private communications.

20) J. Roncali, F. Garnier, M. Lemaire, and R. Garreau, Synth. Metals, 323 (1986).

21) E. Laviron and Y. Mugnier, J. Electroanal. Chem., 111, 337 (1980).

22) J. Bacon and R. N. Adams, J. Am. Chem. Soc., 90, 6596 (1968).

23) R. L. Hand and R. F. Nelson, J. Electrochem. Soc., 125, 1059 (1978).

24) M. M. Baizer, "Organic Electrochemistry", Marcel Dekker, New York (1973).

25) D. M. Mohilner, R. N. Adams, and W. J. Argersinger, Jr., J. Am. Chem. Soc., 84, 3618 (1962).

26) L. R. Sharma, A. K. Manchanda, G. Singh and R. S. Verma, Electrochem. Acta, 27, 223 (1982).

27) A. Volkov, G. Tourillon, P. C. Lacaze, and J. E. Dubois, J. Electroanal. Chem., 115, 279 (1980).

28) Y. Matsuda, A. Shono, C. Iwakura, Y. Ohshiro, T. Agawa, and H. Tamura, Bull. 


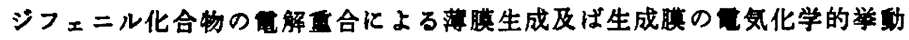

Chem. Soc. Jpn., 44; 2960 (1971).

29) A. D. Cross and R. A. Jones, "An Introduction to Practical Infrared Spectroscopy", 3rd. ed., Butterworth, London (1969).

30) R. E. Parker and R. N. Adams, Anal. Chem., 28, 828 (1956).
31) R. Noufi, A. J. Nozik, J. White, and L. F. Warren, J. Electrochem. Soc., 129, 2261 (1982).

32) A. F. Diaz and J. A. Logan, J. Electroanal. Chem., 111, 111 (1980).

33) 矢野 河, 木谷 晧, 佐々木和夫, 日本化学会 第 51 秋季年会满演予稿集，(1985), p. 22.

Preparation of Thin Films by Electropolymerization of Diphenyl Compounds and Their Electrochemical Properties

Takeo OhSAKA*1, Fumihiro Yoshimura*1, Yukio Ohnuki*1, Yoshimi Ogino*2, Sadako NaKamura*2, and Noboru OYAMA*1

*1 Department of Applied Chemistry for Resources, Tokyo University of Agriculture and Technology (2-24-16 Naka-machi, Koganei, Tokyo, 184 Japan).

*2 Department of Chemistry, Japan Women's University (2-8-1 Mejirodai, Bunkyo-ku, Tokyo, 112 Japan).

The Electropolymerization of diphenyl compounds ( $p$-phenoxyaniline (PA), p-phenoxyphenol (PP), 4aminodiphenylamine (ADA) and 4-hydroxydiphenylamine (HDA)) was carried out under various electrolysis conditions, and the preparation of polymer films and their electrochemical properties and structures were examined. It was found that the electrochemical oxidation of PA, PP and ADA leads to the formation of polymer films PPA, PPP and PADA, respectively, on the electrode surfaces and that these films are electroactive in aqueous solutions. It became also apparent that PPA contains the redox units corresponding to azobenzene-hydrazobenzene, $p$-aminophenol-quinone imine and $p, p^{\prime}$-biphenol-biphenoquinone redox couples and PPP contains those corresponding to $p$-benzoquinone-hydroquinone and $p, p^{\prime}$-biphenol-biphenoquinone redox couples. PADA displayed complicated electrochemical response such as that of electroative polyaniline films. In contrast to PA, PP and ADA, the electrochemical oxidation of HDA did not lead to the corresponding polymeric film formation.

KEY WORDS Electropolymerization / Diphenyl Compounds / p-Phenoxyphenol / p-Phenoxyaniline / 4Aminodiphenylamine / 4-Hydroxydiphenylamine / Electroactive Thin Films /

(Received November 1, 1986: Accepted February 5, 1987)

[Kobunshi Ronbunshu, 44 (4), 305-315 (1987)] 